\title{
Vibrio harveyi: a serious pathogen of fish and invertebrates in mariculture
}

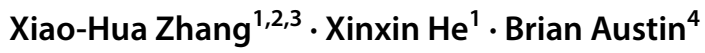

Received: 6 January 2020 / Accepted: 26 February 2020 / Published online: 3 April 2020

(c) The Author(s) 2020

\begin{abstract}
Vibrio harveyi, which belongs to family Vibrionaceae of class Gammaproteobacteria, includes the species V. carchariae and $V$. trachuri as its junior synonyms. The organism is a well-recognized and serious bacterial pathogen of marine fish and invertebrates, including penaeid shrimp, in aquaculture. Diseased fish may exhibit a range of lesions, including eye lesions/blindness, gastro-enteritis, muscle necrosis, skin ulcers, and tail rot disease. In shrimp, $V$. harveyi is regarded as the etiological agent of luminous vibriosis in which affected animals glow in the dark. There is a second condition of shrimp known as Bolitas negricans where the digestive tract is filled with spheres of sloughed-off tissue. It is recognized that the pathogenicity mechanisms of $V$. harveyi may be different in fish and penaeid shrimp. In shrimp, the pathogenicity mechanisms involved the endotoxin lipopolysaccharide, and extracellular proteases, and interaction with bacteriophages. In fish, the pathogenicity mechanisms involved extracellular hemolysin (encoded by duplicate hemolysin genes), which was identified as a phospholipase B and could inactivate fish cells by apoptosis, via the caspase activation pathway. $V$. harveyi may enter the so-called viable but nonculturable (VBNC) state, and resuscitation of the VBNC cells may be an important reason for vibriosis outbreaks in aquaculture. Disease control measures center on dietary supplements (including probiotics), nonspecific immunostimulants, and vaccines and to a lesser extent antibiotics and other antimicrobial compounds.
\end{abstract}

Keywords Vibrio harveyi $\cdot$ Pathogen $\cdot$ Fish $\cdot$ Invertebrates $\cdot$ Aquaculture

\section{Introduction}

Vibrio harveyi, which occurs naturally in marine habitats (Firmino et al. 2019; Zhang et al. 2018), has developed into a significant pathogen of wild and cultured marine fish and invertebrates (notably penaeid shrimp), especially in warm

\section{Edited by Xin Yu.}

Xiao-Hua Zhang

xhzhang@ouc.edu.cn

1 MOE Key Laboratory of Marine Genetics and Breeding, College of Marine Life Sciences, Ocean University of China, Qingdao 266003, China

2 Laboratory for Marine Ecology and Environmental Science, Qingdao National Laboratory for Marine Science and Technology, Qingdao 266237, China

3 Frontiers Science Center for Deep Ocean Multispheres and Earth System, Ocean University of China, Qingdao 266100, China

4 Institute of Aquaculture, University of Stirling, Stirling FK9 4LA, Scotland, UK waters of Asia, southern Europe, and South America. However, $V$. harveyi is not always recovered as a pure culture from diseased animals. Instead, there is some evidence that the pathogen may be recovered in mixed microbial populations, with, for example, V. chagassi (Fabbro et al. 2011). Moreover, V. alginolyticus, V. harveyi, and V. parahaemolyticus were detected in diseased yellow croaker (Pseudosciaena crocea) in China; none of the three bacterial pathogens dominated (Liu et al. 2016). Similarly, V. harveyi was recovered with $V$. alginolyticus from diseased hybrid groupers (Epinephelus polyphekadion $\times$ E. fuscoguttatus) in Malaysia (Mohamad et al. 2019). Of course, it is uncertain whether the presence of two or more bacterial taxa from the same pathological material represents co-culture or the presence of secondary invaders or even chance contaminants. Unfortunately, this aspect of pathology is rarely investigated. This review strives to discuss the biology of $V$. harveyi particularly aspects which appertain to its role as a serious pathogen of mariculture. 


\section{Taxonomy}

Vibrio harveyi is a member of the genus Vibrio, in the family Vibrionaceae, order Vibrionales, class Gammaproteobacteria, and phylum Proteobacteria. The classification of the organism has progressed from its initial name of Achromobacter harveyi (E. N. Harvey was a pioneer in the systematics of bioluminescence; Johnson and Shunk 1936) to Lucibacterium harveyi and Beneckea harveyi to the currently accepted name, V. harveyi (Farmer et al. 2005). Identification of isolates has progressed from phenotypic, serologic to genotypic or polyphasic, including the use of DNA:DNA hybridization when Ishimaru and Muroga (1997) confirmed that pathogenic isolates from milkfish (Chanos chanos) in Japan were definitely $V$. harveyi. A brief phenotypic description mentions that $V$. harveyi comprises Gram-negative, fermentative rod-shaped bacteria, which require for sodium chloride for growth and are motile by polar flagella (Fig. 1a, b). Growth occurs on TCBS (cholera agar=thiosulfate citrate bile salts sucrose agar) (Fig. 1c; Farmer et al. 2005). Some cultures are luminous (Fig. 1d). However, the phenotype may be changed by infection with the Vibrio harveyi myovirus like bacteriophage (VHML) (Vidgen et al. 2006). By 16S rRNA gene or whole-genome sequencing, $V$. harveyi is clearly a core species of Vibrio (Dorsch et al. 1992; Lin et al. 2018).

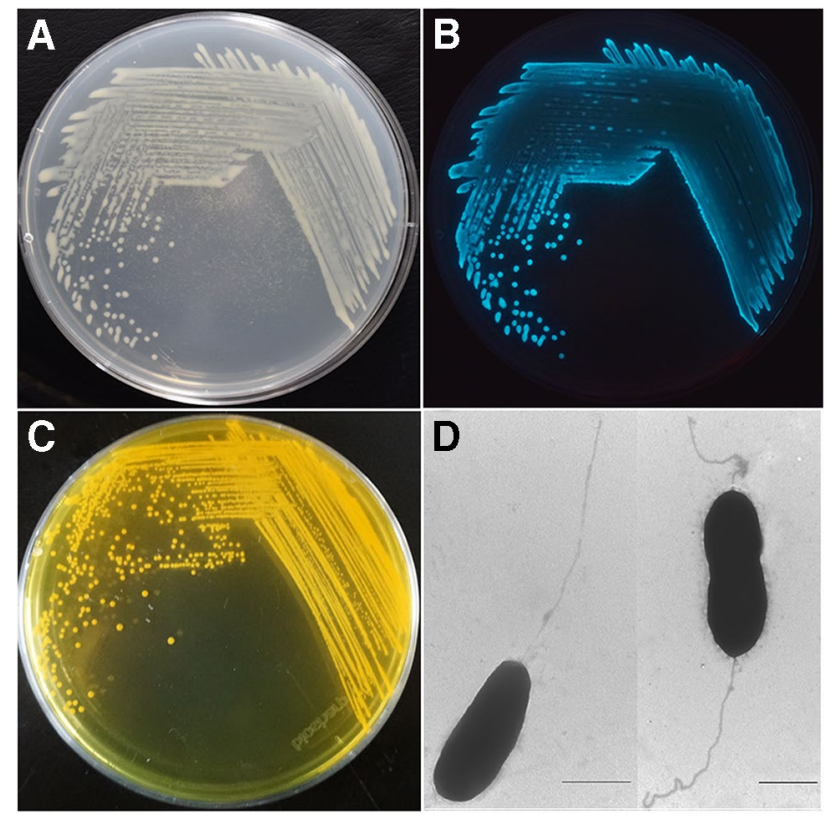

Fig. 1 Morphology of Vibrio harveyi strains. a Growth of V. harveyi VIB 391 on marine agar $2216 \mathrm{E}$; b luminescence of $V$. harveyi VIB 391; c growth of $V$. harveyi VIB 645 on TCBS agar; $\mathbf{d}$ transmission electron microscopy of VIB 645 cells obtained from marine broth culture. Scale $=1 \mu \mathrm{m}$
Vibrio harveyi was linked to V. campbellii by phenotyping and genotyping (Gomez-Gil et al. 2004). They noted that some isolates, which were labeled as $V$. harveyi, belonged in $V$. campbellii. However, multilocus sequence analysis confirmed the distinctness of bona fide isolates of $V$. harveyi and $V$. campbellii, and verified that both species are, indeed, separate entities (Thompson et al. 2007). Certainly, questions have been raised concerning the accuracy of identifying vibrios within the Harveyi clade. This problem may reflect on the associated studies discussed below (Hoffmann et al. 2012; Ke et al. 2017; Urbanczyk et al. 2013).

Vibrio carchariae was named after recovery of an isolate from a dead sandbar shark (Carcharhinus plumbeus) (Grimes et al. 1984) and lemon sharks (Negraprion brevirostris) (Colwell and Grimes 1984). However, detailed taxonomic examination, including the use of 16S rRNA gene sequencing (Gauger and Gomez-Chiarri 2002), led to the recognition that $V$. carchariae and $V$. harveyi are virtually identical, with the name of harveyi having precedence (Farmer and Hickman-Brenner 1992; Gauger and GomezChiarri 2002; Pedersen et al. 1998). It is noteworthy that isolates identified as $V$. carchariae have been isolated from humans, who was bitten by sharks (Pavia et al. 1989).

The fish pathogen $V$. trachuri was named by Iwamoto et al. (1995), but was deduced to be synonymous with $V$. harveyi, with the latter having precedence in taxonomy (Thompson et al. 2002). These workers carried out a detailed polyphasic taxonomy study employing phenotyping, $16 \mathrm{~S}$ rRNA gene sequencing, fluorescent amplified fragment length polymorphisms (FAFLP), and DNA:DNA hybridization. The outcome was the realization that $V$. trachuri was highly related to $V$. harveyi.

Generally, V. carchariae and $V$. trachuri have been recovered from diseased fish, whereas $V$. harveyi was predominantly recovered from invertebrates. Therefore, the combined taxon is especially significant as a pathogen of marine vertebrates and invertebrates.

\section{The diseases}

Vibrio harveyi has been linked with disease in a broad spectrum of warm water fish and invertebrates (Table 1). The list of hosts is extensive, and includes silvery black porgy (Acanthopagrus cuvieri) and brown spotted grouper (Epinephelus tauvina) in Kuwait (Saeed 1995), common dentex (Dentex dentex) and farmed sole (Solea senegalensis) in Spain (Company et al. 1999; Zorrilla et al. 2003), and farmed sea perch (Lateolabrax japonicus) and cage-reared grouper (Epinephelus awoara) in China (Qin et al. 2006; Wang et al. 2002). $V$. harveyi has been often associated with eye disease, for example in common snook (Centropomus undecimalis) (Kraxberger-Beatty et al. 1990), milkfish (Chanos chanos) 
Table 1 Diseases of marine vertebrates and invertebrates attributed to Vibrio harveyi

\begin{tabular}{|c|c|c|c|}
\hline Disease & Host & Geographical range & Key references \\
\hline \multicolumn{4}{|l|}{ Fish } \\
\hline \multirow[t]{3}{*}{ Eye disease } & $\begin{array}{l}\text { Common snook (Centropomus undeci- } \\
\text { malis) }\end{array}$ & USA & Kraxberger-Beatty et al. (1990) \\
\hline & Milkfish (Chanos chanos) & Philippines & Ishimaru and Muroga (1997) \\
\hline & Short sunfish (Mola mola) & Spain & Hispano et al. (1997) \\
\hline \multirow[t]{2}{*}{ Gastro-enteritis } & Grouper (Epinephelus coioides) & Taiwan, China & Yii et al. (1997) \\
\hline & $\begin{array}{l}\text { Various fish, including black sea bream, } \\
\text { Japanese sea bass, yellowfin sea } \\
\text { bream, and red drum }\end{array}$ & Taiwan, China & Lee et al. (2002); Liu et al. (2003) \\
\hline Necrotizing enteritis & $\begin{array}{l}\text { Summer flounder (Paralichthys den- } \\
\text { tatus) }\end{array}$ & USA & $\begin{array}{l}\text { Gauger et al. (2006); Soffientino et al. } \\
\text { (1999) }\end{array}$ \\
\hline Nodules on operculum & Tiger puffer (Takifugu rubripes) & Japan & Mohi et al. (2010) \\
\hline \multirow[t]{2}{*}{ Scale drop and muscle necrosis } & Barramundi (Lates calcarifer) & Vietnam & Dong et al. (2017a) \\
\hline & $\begin{array}{l}\text { Hybrid grouper (Epinephelus fuscogut- } \\
\text { tatus x E. lanceolatus) }\end{array}$ & China & Zhu et al. (2018) \\
\hline \multirow[t]{3}{*}{ Skin ulcers } & Shark (Carcharhinus plumbeus) & Italy & Bertone et al. (1996) \\
\hline & Sole (Solea senegalensis) & Spain & Zorrilla et al. (2003) \\
\hline & $\begin{array}{l}\text { Hybrid grouper (E. fuscoguttatus } x E \text {. } \\
\text { lanceolatus) }\end{array}$ & China & Shen et al. (2017) \\
\hline \multirow[t]{2}{*}{ Tail rot disease } & Sea perch (Lateolabrax japonicus) & China & Wang et al. (2002) \\
\hline & Sea bream (Sparus aurata) & Malta & Haldar et al. (2010) \\
\hline Vasculitis & Brown shark (Carcharhinus plumbeus) & USA & Grimes et al. (1984) \\
\hline \multicolumn{4}{|l|}{ Invertebrates } \\
\hline $\begin{array}{l}\text { Acute hepatopancreatic necrosis } \\
\text { disease }\end{array}$ & $\begin{array}{l}\text { Whiteleg shrimp (Litopenaeus vanne- } \\
\text { mei) }\end{array}$ & Malaysia & Muthukrishnan et al. (2019) \\
\hline Bacterial white tail disease & Litopenaeus vannemei & China & Zhou et al. (2012) \\
\hline Black shell disease & Tiger shrimp (Penaeus monodon) & India & Selvin et al. (2005) \\
\hline Bolitas negricans & Penaeid shrimp & Ecuador & Robertson et al. (1998) \\
\hline Foot pustule disease & Abalone (Haliotis discus hannai) & China & Wang et al. (2018) \\
\hline Luminous vibriosis & Penaeid shrimp & Ecuador, Asia & Prayitno and Latchford (1995) \\
\hline Skin ulceration & Sea cucumber (Holothuria scabra) & Madagascar & Becket et al. (2004) \\
\hline White patch disease & Seahorse (Hippocampus kuda) & India & Raj et al. (2010) \\
\hline White spot on the foot & $\begin{array}{l}\text { Japanese abalone (Sulculus diversi- } \\
\text { color) }\end{array}$ & Japan & Nishimori et al. (1998) \\
\hline
\end{tabular}

in the Philippines (Ishimaru and Muroga 1997), and short sunfish (Mola mola) (Hispano et al. 1997). Without effective chemotherapy, the infected fish would inevitably become blind. In fish, the pathogen has also been attributed with gastro-enteritis, necrotizing enteritis, nodules on the opercula, scale drop and muscle necrosis, skin ulcers, tail rot, and vasculitis in different fish species (Table 1). With the latter infection, the fish were inappetant, lethargic, disoriented, and displayed necrotic subdermal cysts. Internally, meningitis, encephalitis, vasculitis, kidney necrosis, and liver and kidney damage were recorded (Grimes et al. 1985). Also, $V$. harveyi has been associated with a vibriosis-like disease in Japanese horse mackerel (Trachurus japonicus) when water temperatures were $>25{ }^{\circ} \mathrm{C}$ (Iwamoto et al. 1995). Here, fish displayed a diverse pathology, namely melanosis, erratic swimming behavior, bilateral exophthalmia, and hemorrhaging on/in the internal organs (Iwamoto et al. 1995). V. harveyi appears to exert great severity on/in immunosuppressed fish (Grimes et al. 1985).

An interesting situation occurred in Malaysia whereby farmed juvenile hybrid grouper $(E$. polyphekadion $\times E$. fuscoguttatus) experienced losses of $29 \%$ in 10 days with diseased fish becoming lethargic, displaying excessive mucus production, fin rot, congestion of the brain, liver and kidneys, and splenic enlargement. V. alginolyticus and $V$. harveyi were cultured from diseased fish; both organisms exhibited pathogenicity in laboratory-based infectivity experiments. Indeed, use of both organisms administered concurrently led to more severe disease than when single cultures were used (Mohamad et al. 2019).

Vibrio harveyi has been particularly troublesome in shrimp culture. The pathogen has been recovered from 
outbreaks of Bolitas negricans (Spanish = small balls; diseased shrimps contain balled epidermal tissue which can block the digestive tract) in Ecuador (Robertson et al. 1998) and luminous vibriosis (the diseased animals can glow in the dark; Prayitno and Latchford 1995), and linked with black shell disease in tiger shrimp (Penaeus monodon) in India (Selvin et al. 2005) and bacterial white tail disease in whiteleg shrimp (Litopenaeus vannamei) in China (Zhou et al. 2012). With the latter disease, mass mortalities have been reported in which the affected shrimp displayed white or opaque lesions in the tail, which were attributed to muscle necrosis (Zhou et al. 2012).

The pathogen has been cultured from white patch disease in seahorses (Hippocampus kuda) (Raj et al. 2010). This disease, which was characterized by white patches on the surface and anorexia, resulted in high mortalities among the captive seahorses. Also, the pathogen has been associated with disease in lined seahorses (Hippocampus erectus) (Qin et al. 2017). Moreover, Chinese production of Japanese abalone (Haliotis discus hannai) experienced heavy mortalities attributed to $V$. harveyi (Nishimori et al. 1998). The disease signs centered on the presence of white spots on the foot and eventually mortalities (Nishimori et al. 1998). Foot pustule disease was described in Japanese abalone, which were lethargic and weak, and exhibited pustles and atrophying of the foot muscle, leading to mortalities (Wang et al. 2018).

Luminous vibriosis caused by $V$. harveyi was reported in the packhorse rock lobster (Jasus verreauxi) larvae (Diggles et al. 2000). At the beginning of the infection, the larvae developed quickly expanding white spots, with death occurring within three days when the water temperatures were $20-23{ }^{\circ} \mathrm{C}$, and the epidermis within the spots was completely destroyed (Diggles et al. 2000). Skin ulceration caused by $V$. harveyi was also documented in juvenile sea cucumber (Holothuria scabra) in Madagascar (Becket et al. 2004).

Together with $V$. parahaemolyticus, V. owensii (Xiao et al. 2017), V. campbellii (Dong et al. 2017b; Han et al. 2017), and V. punensis (Restrepo et al. 2018), V. harveyi has been reported to cause acute hepatopancreatic necrosis disease (AHPND) in whiteleg shrimp (L. vannamei) in Malaysian shrimp ponds. Moreover, pathogenicity of $V$. harveyi was confirmed in infectivity experiments (Muthukrishnan et al. 2019). This is interesting, because hitherto AHPND was associated exclusively with $V$. parahaemolyticus.

\section{Diagnosis}

Confusion may have resulted previously from reliance on phenotypic diagnostic approaches when misidentification was unknown. Key diagnostic traits, which could allow confusion with $V$. alginolyticus, included the presence of fermentative motile Gram-negative rods that grew at $11-40{ }^{\circ} \mathrm{C}$ in $3-8 \%$ sodium chloride, produced catalase, oxidase, indole, and lysine and ornithine decarboxylase, but not arginine dihydrolase, reduced nitrates, was negative for the Voges Proskauer reaction, and decomposed blood, DNA, and gelatin but not aesculin, casein or starch, and utilized arabinose, cellobiose, glucose, and sucrose but not inositol or lactose (Austin and Austin 2016). However, modern molecular approaches have heightened the accuracy of diagnoses, and include 16S rRNA gene sequencing, which has become the favored method of identifying isolates accurately (Ransangan and Mustafa 2009) and multilocus sequence analysis, which successfully identified 36 isolates from Australia (Cano-Gomez et al. 2011). It is noteworthy that a polymerase chain reaction (PCR) based on the $V$. harveyi toxR gene was sensitive, i.e., capable of detecting $4.0 \times 10^{3}$ cells $/ \mathrm{ml}$, and specific to $V$. harveyi but no other vibrios (Pang et al. 2006). However, a PCR was developed, which was based on the conserved sequence of the gene encoding the OMP $v h h P 2$, and was shown to be quick and fairly specific, although some $V$. campbellii cultures cross reacted and were misidentified as $V$. harveyi (Cano-Gomez et al. 2011). Success has been reported for a multiplex PCR, which was both specific and sensitive (Pinto et al. 2017). Similarly, an enterobacterial repetitive intergenic consensus (ERIC)-PCR was developed and regarded as effective for detection of the pathogen (Xu et al. 2017). A highly sensitive [60 colonyforming units (CFU) per reaction] and specific recombinase polymerase amplification (RPA) was designed specifically to recognize the $V$. harveyi tox $R$ gene. The researchers considered that the technique was fast and accurate, permitting effective monitoring of disease outbreaks (Pang et al. 2019).

Serological approaches have garnered support. For example, a chemiluminescent-based dot blot incorporating monoclonal antibodies was described, and invoked a brief $2-\mathrm{h}$ incubation leading to a limit of detection of $2 \times 10^{5} / \mathrm{ml}$; this was regarded as 50 times more sensitive than the conventional dot blot, and was superior $(\sim 1000$ times more sensitive) to the indirect enzyme-linked immunosorbent assay (Li et al. 2017).

\section{Pathogenic mechanisms}

We will preface remarks by stating that much of the research on pathogenicity has involved use of laboratory cultures, some of which are of uncertain authenticity/identity. Therefore, there may be questions concerning whether or not the research has actually used genuine $V$. harveyi cultures, and the actual relevance of the data to the host. An initial conclusion may be reached that the pathogenicity mechanisms remain to be properly resolved. Nevertheless, infections and mortalities have been achieved using fish and cultures. For 
example, using $V$. trachuri and Japanese horse mackerel (Trachurus japonicus), which were maintained at a water temperature of $26{ }^{\circ} \mathrm{C}, 1.1 \times 10^{8}$ cells/fish were injected intraperitoneally, and led to $100 \%$ mortalities within $24 \mathrm{~h}$. However, using only $1.1 \times 10^{7}$ cells/fish, a total of $50 \%$ mortalities occurred in four days. In comparison, immersion in $3.6 \times 10^{7}$ cells $/ \mathrm{ml}$ for $2 \mathrm{~min}$ led to $100 \%$ mortalities in three days. The disease signs matched those of naturally infected fish, namely erratic swimming and melanosis (Iwamoto et al. 1995). Yii et al. (1997) reported an $\mathrm{LD}_{50}$ dose for grouper (Epinephelus coioides) of $2.53 \times 10^{7} \mathrm{CFU} / \mathrm{g}$ of fish. Moreover, they noted that the disease signs were similar to those of the natural infection, namely that the intestine was swollen and full of yellowish fluid. In comparison, Pujalte et al. (2003) reported an $\mathrm{LD}_{50}$ value of $1.5 \times 10^{5}$ to $1.6 \times 10^{6} \mathrm{CFU} / \mathrm{fish}$ for European sea bass (Dicentrarchus labrax). Similarly, Won and Park (2008) found the $\mathrm{LD}_{50}$ dose to Japanese flounder (Paralichthys olivaceus) and black rockfish (Sebastes schlegeli) to be $2.48 \times 10^{5}-8.76 \times 10^{7}$ and $2.0 \times 10^{4}-2.52 \times 10^{6} \mathrm{CFU} / \mathrm{g}$ of fish, respectively.

Therefore, how does the host respond to invasion by $V$. harveyi? Using suppression subtractive hybridization ( $\mathrm{SSH}$ ) technique, Wang et al. (2008) identified several immunerelated genes, such as a heat shock protein (HSP) 70 gene and a major histocompatibility complex (MHC) class 1a gene, from kidney and spleen of turbot (Scophthalmus maximus) infected by $V$. harveyi. The rapid transcriptional upregulation after $V$. harveyi infection may be important for the survival of fish (Wang et al. 2008). Moreover, pathogenic $V$. harveyi isolates from diseased Japanese flounder were more resistant to the bactericidal effects of fish serum, and caused elevated respiratory burst activity in head kidney macrophages of the host. Apoptosis was induced in cultured fish cells, leading to apoptotic bodies, DNA fragmentation, and enhanced caspase-3 activity ( $\mathrm{Li}$ et al. 2011).

Many virulence factors, such as hemolysins, proteases, lipopolysaccharide (LPS), the capacity to bind iron, interaction with bacteriophages, biofilm formation, and quorum sensing, have been identified (Table 2 and see below for details). It is certainly possible that pathogenicity reflects the interaction between two or more virulence factors functioning together or sequentially (Won and Park 2008). Moreover, it is important to realize that the pathogenicity mechanisms of $V$. harveyi to fish and invertebrates may well be different (Owens et al. 1996; Zhang 2001).

\section{Ability to bind iron}

It has been argued that the ability of pathogens to bind iron may be important for fish but not for invertebrates (Owens et al. 1996).

\section{Bacteriocin-like substances (BLIS)}

BLIS was isolated from a culture, which was pathogenic to salmonids, i.e., V. harveyi VIB 571, and determined to be inhibitory to four other $V$. harveyi isolates and to other Vibrio spp., e.g., V. parahaemolyticus. BLIS was prepared from culture supernatants, and characterized as a unique protein with a molecular weight of $\sim 32 \mathrm{kDa}$ (Prasad et al. 2005).

\section{Bacteriophage}

Bacteriophages have been associated with virulence (Austin et al. 2003; Oakey and Owens, 2000). In particular, V. harveyi myovirus like (VHML) phage is a temperate bacteriophage with a narrow host range that could enhance and even restore virulence of $V$. harveyi isolates to Atlantic salmon (Salmo salar L.) and increase hemolytic activity (Austin et al. 2003; Oakey et al. 2002). Infecting an avirulent $V$. harveyi strain VIB 642 with VMHL led to virulence and upregulation of hemolysin secretion (Munro et al. 2003). Knowledge of VMHL increased as the complete nucleotide sequence and the open-reading frame (ORF) were determined (Oakey et al. 2002). Furthermore, it has been suggested that bacteriophage may mediate toxicity of isolates in tiger shrimp by transfer of one or more toxin genes or genes

Table 2 Pathogenicity mechanisms

\begin{tabular}{ll}
\hline Pathogenicity mechanisms & Key references \\
\hline Ability to bind iron & Owens et al. (1996) \\
Bacteriocin-like substance & Prasad et al. (2005) \\
Bacteriophage & Austin et al. (2003); Munro et al. (2003); Oakey and Owens (2000); Ruangpan et al. 1999 \\
Biofilm—formation and attachment & Karasunagar et al. (1994) \\
Extracellular product—cysteine protease & Liu et al. (1996) \\
Extracellular product-lipopolysaccharide & Montero and Austin (1999) \\
Extracellular product-hemolysin & Bai et al. (2010); Deane et al. 2012; Sun et al. (2007); Zhang et al. (2001); Zhong et al. (2006) \\
Luminescence and quorum sensing & Henke and Bassler (2004); Nakayama et al. (2005); Yang et al. (2011) \\
Resuscitation from VBNC state & Sun et al. (2008) \\
\hline
\end{tabular}


controlling toxin production (Ruangpan et al. 1999). Subsequently, a novel siphovirus-like phage 1 (VHS1) was recovered, but a connection with virulence remains to be established (Khemayan et al. 2006; Pasharawipas et al. 2005).

\section{Biofilms}

Biofilms form when organisms are attracted towards or arrive by accident at a surface, become attached, and then multiply. Specific attachment to chitin by means of chitinbinding proteins is an important mechanism for adhesion and colonization of $V$. harveyi (Montgomery and Kirchman 1993, 1994). Research has demonstrated that $V$. harveyi may survive in shrimp hatcheries due to the ability to form biofilms, which confer resistance to antibiotics and disinfectants (Karunasagar et al. 1994).

\section{Extracellular products (ECP)}

Vibrio harveyi has been reported as slightly cytotoxic to fish and invertebrates, and produces ECP (Table 2; Liu et al. 1996; Won and Park 2008; Zhang and Austin 2000), which comprise hemolysins (Li et al. 2011; Zhang and Austin 2000), caseinase, gelatinase, lipase, and phospholipase (Liu et al. 1996; Zhang and Austin 2000). When brine shrimp (Artemia franciscana) nauplii were injected with a range of $V$. harveyi strains, correlations between mortality of brine shrimp and production of proteases, phospholipases, or siderophores of $V$. harveyi cultures were observed, but there is no correlation between mortality and hemolytic activity, hydrophobicity, or lipase or gelatinase production (Soto-Rodriguez et al. 2003). A $22 \mathrm{kDa}$ extracellular cysteine protease has been purified (Fukasawa et al. 1988a, b; Liu et al. 1997) and considered to be the major exotoxin to tiger prawns (Lee 1996; Lee et al. 1997; Liu and Lee 1996). Moreover, Harries and Owens (1999) isolated two proteins, which caused mortalities in tiger prawns, and were regarded as both exotoxins and the probable virulence factors. When the ECP of pathogenic strain E2 was heated at $100{ }^{\circ} \mathrm{C}$ for 10 min or digested with proteinase $\mathrm{K}$, it produced the same pathology in Dublin Bay prawns (Nephrops norvegicus) as crude, untreated ECP. Western blotting revealed the presence of low-molecular-weight LPS, which was considered to constitute the lethal toxin (Montero and Austin 1999). However, the same strain was not pathogenic to rainbow trout (Oncorhynchus mykiss) (Zhang 2001), indicating that the pathogenicity mechanisms of $V$. harveyi to shrimp and fish may well be different.

\section{Hemolysins in the ECP}

Zhang and Austin (2000) reported that the most highly pathogenic culture in their study was $V$. harveyi VIB 645, which produced ECPs with the highest titer of hemolytic activity to both Atlantic salmon and rainbow trout erythrocytes. They further correlated virulence of $V$. harveyi to salmonids with the possession of duplicate hemolysin genes, i.e., $v h h A$ and $v h h B$. The majority (19/20) of the less virulent or avirulent cultures possessed single genes or none at all (Zhang et al. 2001). The open-reading frame (ORF) of the $v h h A$ and $v h h B$ genes was calculated to be 1257 nucleotides in length, which matches the th gene of $V$. parahaemolyticus (Nishibuchi and Kaper 1985). VHH hemolysin was determined to be homologous with lecithinase of $V$. cholerae and $V$. mimicus. The $v h h A$ gene was overexpressed in Escherichia coli, and the purified recombinant VHH hemolysin was found to be cytotoxic to Japanese flounder gill cells. The protein caused mortalities in Japanese flounder with the $\mathrm{LD}_{50}$ dose calculated as $18.4 \mu \mathrm{g}$ of protein/fish (Zhong et al. 2006). Sun et al. (2007) identified VHH hemolysin as a phospholipase $\mathrm{B}$, and reported that a single residue change (Ser153) in the VHH hemolysin resulted in loss of hemolysin and phospholipase activities, and pathogenicity to turbot. In experiments involving immunolocalization of VHH in tissues of Japanese flounder challenged by the protein, the hemolysin was observed to be confined mainly to intestinal epithelial and gill epithelial cells (Fig. 2), indicating that the intestines and gills may be the primary targets for the invasion of $V$. harveyi in fish (unpublished data). In addition, recombinant VHH hemolysin induced various apoptotic features (such as
Fig. 2 Immunohistochemical localization of recombinant VHH from Vibrio harveyi in tissues of Japanese flounder injected with VHH. Rabbit antiVHH antibody was used as primary antibody and horseradish peroxidase (HRP)-labeled goat anti-rabbit antibody was used as the secondary antibody. Positive staining (arrows) in intestine (a) and gill (b). Bar $=20 \mu \mathrm{m}$

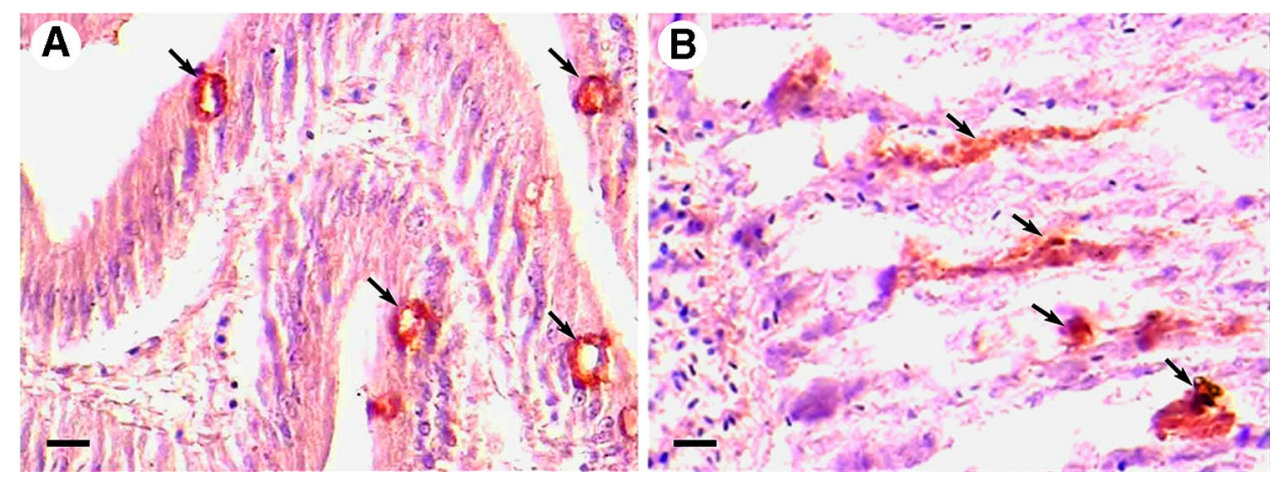


apoptotic bodies, chromatin condensation, increased number of TUNEL-positive apoptotic cells, and caspase-3 activity) in Japanese flounder gill cell line. These data led to the conclusion that VHH inactivated these cells by apoptosis, via the caspase activation pathway (Bai et al. 2010). Moreover, VHH induced apoptosis in silver sea bream (Sparus sarba) and black sea bream (Mylio macrocephalus) fibroblast cell lines. This featured reduced mitochondrial membrane potential prior to increased caspase-3 activity. In short, it was highlighted that hemolysin led to cell death by induction of apoptosis (Deane et al. 2012).

\section{Luminescence and quorum sensing}

Some $V$. harveyi strains possess luminescence characteristics when grown either in vitro or in vivo (Fig. 1b; Zhang 2001). Luminous vibriosis is so named, because diseased shrimp luminesce, i.e., glow in the dark (Prayitno and Latchford 1995). This raises the question concerning the role of luminescence in virulence. Luminescence may be verified by monitoring the expression of the LuxR gene in quorum sensing. Research has shown that the expression of LuxR and toxicity to shrimp was most important in relation to luminescence (Nakayama et al. 2005). V. harveyi had been confirmed to have all three types, i.e., AHL, AI-2, and CAI1, of quorum-sensing activities (Yang et al. 2011). Additionally, quorum sensing regulates other virulent factors, such as type III secretion system (Henke and Bassler 2004).

\section{Resuscitation from the viable but nonculturable (VBNC) state}

The VBNC state was first described by Xu et al. (1982), and referred to a state where bacteria remain viable and metabolically active, but are not culturable on standard bacteriological growth media. It is reasoned that the VBNC state is a survival strategy, which has been used by bacteria in response to harsh environmental conditions, and the bacterial cells in VBNC state can return to activity and culturability under appropriate circumstances (Oliver 2010). Sun et al. (2008) determined that $V$. harveyi could enter VBNC state, and the VBNC cells could be resuscitated via an increase in temperature when grown in the presence of yeast extract and Tween 20 or vitamin B. The resuscitation of dormant cells may well be one of the important reasons for vibriosis outbreaks in aquaculture.

\section{Disease control}

The spread of disease associated with $V$. harveyi has inevitably led to a multiplicity of studies aimed at control. Interest started with the use of antimicrobial compounds of which
Prefuran (Argent) administered at $0.1 \mathrm{mg} / \mathrm{L}$ for an unspecified period (Kraxberger-Beatty et al. 1990) and oxytetracycline (Saeed 1995) were successful. However, the concern over tissue residues and the development and spread of antibiotic resistance contributed to research in other areas of disease control, notably preventative rather curative.

\section{Bacteriophage therapy}

Some research has focused on bacteriophage therapy to control luminous vibriosis in shrimp aquaculture (Choudhury et al. 2019). A lytic Myoviridae, VhKM4, was recovered (Lal et al. 2017). Moreover, a cocktail of three bacteriophages of the Myoviridae and Siphoviridae, which were isolated from shrimp farms in India, inhibited $V$. harveyi, led to greater survival of tiger shrimp larvae compared to controls (Stalin and Srinivasan 2017).

\section{Biological control}

Surface-associated bacteria, i.e., Exiguobacterium acetylicum, were recovered on dilution plates from sea cucumber (Stichopus badionotus) and used successfully to control $V$. harveyi disease in brown-marbled grouper fingerlings (Epinephelus fuscoguttatus) (Alipiah et al. 2016). Rearing Pacific white shrimp (Litopeanaeus vannamei) in biofloc has been suggested to reduce hepatopancreas lesions attributed to $V$. harveyi (Aguilera-Rivera et al. 2017).

\section{Dietary supplements}

A wide range of dietary supplements have been proposed for the control of $V$. harveyi. Some have been commercialized particularly in the Far East for use with fish and shellfish (e.g., Geng et al. 2012). Other examples for use in fish include $\beta$-1,3-glucan (Lee et al. 2018), bovine lactoferrin (Esmaeili et al. 2019), Chaga mushroom (Harikrishnan et al. 2012a), the seed of the evergreen tree Leucaena leucocephala (Verma et al. 2018), garlic (Allium sativum) (Talpur and Ikwanuddin 2012), ginger (Zingiber officinale), green tea (Camellia sinensis) (Harikrishnan et al. 2011b), hawthorn (Crataegus sp.) extract (Tan et al. 2017), Japanese pepper tree (Zanthoxylum piperitum) (Harikrishnan et al. 2012d), kudzu (Pueraria thunbergiana) (Harikrishnan et al. 2012b), loquat tree (Eriobotrya japonica) (Kim et al. 2011), and pericarp (Zanthoxylum piperitum) (Harikrishnan et al. 2012a). Immunomodulation and protection against challenge were common to these dietary supplements. For example, Chaga mushroom, when fed for 30 days as an ethanolic extract at $1.0 \%$ and $2.0 \%$ to kelp grouper (Epinephelus bruneus), was reported to achieve increased weight, immunomodulation, and protection against challenge with $V$. harveyi (Harikrishnan et al. 2012a). 
Numerous dietary supplements have been researched for use with shrimp, and include black nightshade (Solanum nigrum) extract (Harikrishnan et al. 2011a) and mangrove (Rhizophora apiculata) leaf extract (Kannappan et al. 2018). Feeding $0.1 \%$ and $1.0 \%$ black nightshade, Harikrishnan et al. (2011a) reported significantly enhanced hemocyte count, glutathione peroxidase, phagocytic, phenoloxidase, respiratory burst and superoxide dismutase activities, and protection against infection with $V$. harveyi.

Probiotics have been evaluated for control of $V$. harveyi infections. For example, Bacillus coagulans achieved success when fed at $10^{9}$-cells/g of feed to the freshwater prawn, Macrobrachium rosenbergii. After 60 days, there was improved growth, significantly enhanced lysozyme and respiratory burst activities, and increased resistance to challenge (Gupta et al. 2016). Schaeck et al. (2016) were an advocate of $V$. lentus, which protected gnotobiotic (= germfree) sea bass (Dicentrarchus labrax) larvae against challenge with $V$. harveyi. The benefits of feeding marine red yeast, Rhodotorula mucilaginosa, at $1.0 \mathrm{~g} / \mathrm{kg}$ for eight weeks have been extolled (Zhou et al. 2016). In addition, it was found that a marine antagonistic strain Pseudoalteromonas flavipulchra JG1 could inhibit the growth of $V$. harveyi (Jin et al. 2010). From this culture, several small molecule compounds (p-hydroxybenzoic acid, trans-cinnamic acid, and 6-bromoindolyl-3-acetic acid) with inhibitory effect to $V$. harveyi were purified (Yu et al. 2012). This bacterial strain could be used as a potential probiotic to control $V$. harveyi disease.

A common theme with the dietary supplements is evidence for improved growth performance, immunomodulation notably of cellular and innate immunity, and protection against challenge with $V$. harveyi. This raises the question concerning the reason(s) for the profound benefit of what is essentially the addition a small quantity of dietary supplement. Could the reason reflect inadequacies in the formulation of diets or are these truly supplements, i.e., supplementing already adequate feed?

\section{Inhibition of quorum sensing}

Quorum-sensing signal molecules may be involved in regulating virulence. In this connection, the $28 \mathrm{kDa}$ AiiA protein of Bacillus thuringiensis interfered with quorum sensing in $V$. harveyi, and could be considered for involvement in disease control strategies (Bai et al. 2008).

\section{Vaccines}

Although vaccines are primarily used to control diseases of fish, some commercial products containing $V$. harveyi antigens have been marketed for the control of shrimp diseases in the Far East. Nevertheless, most of the research has been directed at the control of fish disease.

There has been a dramatic improvement in the success of vaccines for the control of $V$. harveyi diseases reflecting some excellent science (Table 3). Efforts started with the traditional approach of inactivated whole-cell preparations before progression to consideration of purified subcellular components, and subsequently to the modern era of DNA vaccines.

Whole-cell vaccines In their simplest form, whole-cell vaccines comprise bacterial suspensions, which have been inactivated with chemicals, typically formalin. Whole-cell vaccines have gained considerable success with the control of some fish diseases, and numerous examples have been commercialized, worldwide. The approach has been used to control diseases attributed to $V$. harveyi. For example, a

Table 3 Methods of disease control

\begin{tabular}{ll}
\hline Method of disease control & Key reference(s) \\
\hline Antimicrobial compound & Kraxberger-Beatty et al. (1990); Saeed (1995) \\
Bacteriophage therapy & Choudhury et al. (2019); Stalin and Srinivasan (2017) \\
Biological control & Aguilera-Rivera et al. (2017); Alipiah et al. (2016) \\
Dietary supplements-fish & Esmaeili et al. (2019); Lee et al. (2018) \\
Dietary supplements-invertebrates & Harikrishnan et al. (2011a); Kannappan et al. (2018) \\
$\begin{array}{l}\text { Dietary supplements-probiotics } \\
\text { Inhibition of quorum sensing }\end{array}$ & Gupta et al. (2016); Schaeck et al. (2016) \\
Vaccines-whole-cell vaccines & Bai et al. (2008) \\
& Crosbie and Nowak (2004); Harikrishnan et al. (2012b, c); Huang et al. (2012); Nguyen et al. (2017); Xu \\
Vaccines-subunit vaccines & Atujona et al. (2019); Mao et al. (2011); Nguyen et al. (2018); Pang et al. (2010); Zhang et al. (2008); Zhu \\
Vaccines-live vaccines & et al. (2019) \\
Vaccines-DNA vaccines & Cheng et al. (2010); Chin et al. (2020); Hu et al. (2011); Mohd-Aris et al. (2019); Sun et al. (2009) \\
Immunostimulation & Baletal and Gomez-Chiarri (2016) \\
\hline
\end{tabular}


whole-cell vaccine administered by a variety of techniques, i.e., intraperitoneal injection, anal intubation, and, by immersion, to barramundi (Lates calcarifer) led to demonstrable antibody production. Clearly, the data revealed that barramundi could mount an immune response to vaccination (Crosbie and Nowak 2004). A bivalent vaccine comprising formalized cells of $V$. harveyi and Photobacterium damselae subsp. piscicida together with ECP was used in sole both involving immersion together with a booster dose or by i.p. injection. The outcome was excellent protection [relative percent survival (RPS $=\sim 88 \%$ ) for a 4-month period after vaccination]. Subsequently, protection declined (Arijo et al. 2005). A multivalent inactivated vaccine including cells of $V$. alginolyticus, $V$. harveyi, $V$. vulnificus, and infectious spleen and kidney necrosis virus was administered to groups of orange-spotted grouper (Epinephelus coioides) leading to excellent protection after challenge (RPS $=80 \%$; Huang et al. 2012). The commercial attraction to inactivated whole vaccines is that they are comparatively inexpensive to produce. Consequently, research has been directed towards improving the performance of these vaccines, such as by entrapping the antigens in liposomes (Harikrishnan et al. 2012c). Use of CpG oligodeoxynucleotide 1668-enriched plasmid $(\mathrm{p} 60 \mathrm{CpG})$ as an adjuvant with formalized cells led to protection (RPS $=96.2 \%$ ) in orange-spotted grouper (Nguyen et al. 2017). This led to immunomodulation and increased protection (Harikrishnan et al. 2012b). A similar positive effect resulted from the addition of adjuvant, Montanide, to formalin-inactivated cells, which were used to inject turbot. The vaccine was administered at $1.0 \times 10^{8}$ cells/fish leading to an RPS of $75 \%$ after four weeks (Xu et al. 2019).

Subunit vaccines. Many articles have been published showing the success of subunit vaccines. ECPs, outer membrane proteins (OMP) (Arijo et al. 2008), and the hemolysin protein expressed in yeast (Saccharomyces cerevisiae) (Zhu et al. 2006) were immunogenic. Pang et al. (2010) described the use of OmpN mixed with Freunds complete adjuvant (FCA) to administer by i.p. injection (dose $=100 \mu \mathrm{l} / \mathrm{fish}$ ) estuary cod (Epinephelus coioides) leading to an RPS or $60 \%$ or $70 \%$ depending on the challenge culture. A recombinant fusion protein $\mathrm{r}-\mathrm{OmpK}-\mathrm{OmpU}$ controlled disease in orange-spotted grouper (RPS $=81.8 \%$ ) (Nguyen et al. 2018). Subsequently, the OMP To1C, which is a major adhesin, was used successfully to protect hybrid grouper (E. fuscoguttatus $\times$ E. lanceolatus) against experimental challenge (Zhu et al. 2019).

Molecular approaches to vaccine development have met with some success as illustrated by the study of Zhang et al. (2008), who cloned OMP genes, OmpK and GADPH; the recombinant proteins from which were expressed in the vector pET-30a(+). After purification of the protein, $100 \mu \mathrm{g}$ quantities/fish were injected intraperitoneally into groups of yellow croaker (Pseudosciaena crocea). A booster dose was administered at three weeks. Use of r-OmpK and r-GADPH led to RPS values of $37.7 \%$ and $40 \%$, respectively. Although some protection occurred, the levels were not as good as some of the studies using simpler whole-cell vaccines. In a subsequent development, expression of OmpK was achieved using the yeast Pichia pastoris. Experiments used groups of sea bass (Lateolabrax japonicus) and oral uptake of OmpK in alginate microspheres for five days. The outcome was an RPS of 61.5\% (Mao et al. 2011). A recombinant protein vaccine, which was developed from the VirB11 gene, was trialed in groups of orange-spotted grouper. After challenge, an RPS of $88 \%$ was achieved (Atujona et al. 2019).

Live vaccines. We have two concerns about live vaccines that need to be voiced. First, what is the possibility that the presence of live vaccines cells in and around a fish holding facility could be mistaken for the presence of a population of viable pathogens cells? The presence of such viable cells could confuse diagnostics. The second concern revolves around whether or not it is possible for an attenuated vaccine cell to acquire virulence determinants in the aquatic environment. There is not any evidence for these concerns, but it is considered necessary for scientists to be aware of and not ignore the issues. The attraction for live vaccines is that their use is more likely to mimic the infection process of viable pathogens. Therefore, the host responses are likely to be more natural and protective!

A live recombinant vaccine based on the OMP VhhP2 was injected intraperitoneally leading to excellent protection of Japanese flounder (RPS $=92.3 \%$ ) (Sun et al. 2009). This was followed by a series of vaccination studies leading to commendable levels of protection. Thus, Cheng et al. (2010) used a recombinant protein, Vhp1, which when expressed in Escherichia coli and used as a live vaccine achieved an RPS of $90 \%$. A live recombinant vaccine was developed by $\mathrm{Hu}$ et al. (2011), who expressed DegQ. The vaccine was injected intraperitoneally into turbot leading to an RPS of $90.9 \%$. By oral and immersion, ROS values of $60.5 \%$ and $47.1 \%$, were recorded, respectively. The vaccine was used by oral and immersion in a field trial leading to RPS values of $77.8 \%$ after a month and $81.8 \%$ after two months (Hu et al. 2011). A study by Mohd-Aris et al. (2019) involved a live proteasedeletion mutant of $V$. harveyi, which was used to vaccinate grouper (Epinephelus fuscoguttatus) intraperitoneally with a dose equivalent to $10^{5}$ colony-forming units/fish. Following challenge after four weeks, an RPS of 52\% was recorded (Mohd-Aris et al. 2019). A live-attenuated V. harveyi culture MVh_vhs (LAVh) was used in a 1-h bath with Asian seabass (Lates calcarifer) fingerlings leading to $68 \%$ survival after challenge (Chin et al. 2020).

DNA vaccines. A DNA vaccine, pcDNA-GPx, was developed by incorporating the glutathione peroxidase $G P x$ gene into the pcDNA3.1 (+) plasmid, which was injected intramuscularly into orange-spotted groupers leading after 
challenge to an RPS of $77.5 \%$ (Wang et al. 2017). Wang et al. (2011) achieved as RPS of $100 \%$ in turbot using the purified $35 \mathrm{kDa}$ OMP OmpU at a $50 \mu \mathrm{g}$ dose applied by intramuscular injection. A DNA vaccine in which the ompU gene was inserted into pEGFP-N1 plasmid was less successful when injected in $10 \mu \mathrm{g}$ quantities intramuscularly in turbot. With this, the RPS was only 51.4\%. DegQ and Vhp1 were incorporated into a DNA vaccine for use in Japanese flounder in which the resulting RPS was $84.6 \%$ (Hu and Sun 2011).

Although many publications have been encouraging in terms of success of vaccines after challenge, it remains to be determined which vaccines could be produced at the price that the users would be prepared to pay.

\section{Immunostimulation}

Summer flounder (Paralichthys dentatus) were immersed or injected intraperitoneally with a hot water extract of brown seaweed (Sargassum oligocystum) leading to significant stimulation of respiratory burst and hematocrit, and less mortalities after challenge (Sargassum oligocystum) (Baletal and Gomez-Chiarri 2016).

\section{Conclusions}

Vibrio harveyi is a serious pathogen for multiple species of marine fish and invertebrates particularly occurring in the warm waters of Asia, southern Europe, and South America. Some confusion has resulted with identification of cultures, particular centering on distinguishing $V$. harveyi and $V$. campbellii. However, taxonomy studies have confirmed the uniqueness of both of these species. Although virulence has been demonstrated with multiple isolates, there is a lack of clarity over the precise pathogenicity mechanisms, possibly reflecting differences between isolates as well as between fish and invertebrates, and overreliance on laboratory cultures, which are not necessarily reflective of the abilities of fresh isolates. Certainly, hemolysin has been the most extensively studied virulence factor of $V$. harveyi to date. Some excellent work has been accomplished, and it is realized that hemolysin is capable of killing fish cells by apoptosis via the caspase activation pathway. Maybe, key virulence genes, such as occur on plasmids and bacteriophages, become lost with storage of the so-called laboratory cultures. Fortunately, there has been much progress with the development of effective disease control strategies, including use of dietary supplements and vaccines. Clearly, further work is justified to better under this serious pathogen of marine animals.
Acknowledgements The work was supported by the National Key Research and Development Program of China (No. 2018YFE0124100), the National Natural Science Foundation of China (Nos. 41730530 and 91751202), and Marine S \& T Fund of Shandong Province for Pilot National Laboratory for Marine Science and Technology (Qingdao) (No. 2018SDKJ0406-4).

Author contributions $\mathrm{X}-\mathrm{HZ}$ conceived the idea to this work and wrote the manuscript; BA wrote the manuscript; $\mathrm{XH}$ performed the experiments and prepared the figures. All authors edited and approved the final manuscript.

\section{Compliance with ethical standards}

Conflict of interest The authors declare that they have no conflict of interest.

Animal and human rights statement This article does not contain any studies with human participants or animals performed by any of the authors.

Open Access This article is licensed under a Creative Commons Attribution 4.0 International License, which permits use, sharing, adaptation, distribution and reproduction in any medium or format, as long as you give appropriate credit to the original author(s) and the source, provide a link to the Creative Commons licence, and indicate if changes were made. The images or other third party material in this article are included in the article's Creative Commons licence, unless indicated otherwise in a credit line to the material. If material is not included in the article's Creative Commons licence and your intended use is not permitted by statutory regulation or exceeds the permitted use, you will need to obtain permission directly from the copyright holder. To view a copy of this licence, visit http://creativecommons.org/licenses/by/4.0/.

\section{References}

Aguilera-Rivera D, Escalante-Herrera K, Gaxiola G, Prieto-Davó A, Rodríguez-Fuentes G, Guerra-Castro E, Hernández-López J, Chávez-Sánchez MC, Rodríguez-Canul R (2017) Immune response of the Pacific white shrimp, Litopenaeus vannamei, previously reared in biofloc and after an infection assay with Vibrio harveyi. J World Aquac Soc 50:119-136

Alipiah NM, Ramli NHS, Low C-F, Shamsudin MN, Yusoff FM (2016) Protective effects of sea cucumber surface-associated bacteria against Vibrio harveyi in brown-marbled grouper fingerlings. Aquacult Env Interac 8:147-155

Arijo S, Rico R, Chabrillon M, Diaz-Rosales P, Martínez-Manzanares E, Balebona MC, Toranzo AE, Moriñigo MA (2005) Effectiveness of a divalent vaccine for sole, Solea senegalensis (Kaup), against Vibrio harveyi and Photobacterium damselae subsp. piscicida. J Fish Dis 28:33-38

Arijo S, Brunt J, Chabrillón M, Díaz-Rosales P, Austin B (2008) Subcellular components of Vibrio harveyi and probiotics induce immune responses in rainbow trout, Oncorhynchus mykiss (Walbaum), against $V$. harveyi. J Fish Dis 31:579-590

Atujona D, Huang YC, Wang ZW, Jian JC, Cai SH (2019) Vibrio harveyi (VirB11) recombinant vaccine development against vibriosis in orange-spotted grouper (Epinephelus coioides). Aquac Res 50:2628-2634

Austin B, Austin DA (2016) Bacterial fish pathogens: disease of farmed and wild fish, 6th edn. Springer, Dordrecht, pp 499-601 
Austin B, Pride AC, Rhodie GA (2003) Association of a bacteriophage with virulence in Vibrio harveyi. J Fish Dis 26:55-58

Bai F, Han Y, Chen J, Zhang X-H (2008) Disruption of quorum sensing in Vibrio harveyi by the AiiA protein of Bacillus thuringiensis. Aquaculture 274:36-40

Bai F, Sun B, Woo NYS, Zhang X-H (2010) Vibrio harveyi hemolysin induces ultrastructural changes and apoptosis in flounder (Paralichthys olivaceus) cells. Biochem Biophys Res Commun 395:70-75

Baletal FN, Gomez-Chiarri M (2016) Effect of Sargassum oligocystum hot-water extract on innate immune response and survival of summer flounder Paralichthys dentatus to Vibrio harveyi challenge. Isr J Acquacult-bamid 68:1289

Becket P, Gillan D, Lanterbecq D, Jangoux M, Rasolofonirina R, Rakotovao J, Eeckhaut I (2004) The skin ulceration disease in cultivated juveniles of Holothuria scabra (Holothuroidea, Echinodermata). Aquaculture 242:13-30

Bertone S, Gili C, Moizo A, Calegari L (1996) Vibrio carchariae associated with a chronic skin ulcer on a shark, Carcharhinus plumbeus (Nardo). J Fish Dis 19:429-434

Cano-Gomez A, Hoj L, Owens L, Andreakis N (2011) Multilocus sequence analysis provides basis for fast and reliable identification of Vibrio harveyi-related species and reveals previous misidentification of important marine pathogens. Syst Appl Microbiol 34:561-565

Cheng S, Zhang W-W, Zhang M, Sun L (2010) Evaluation of the vaccine potential of a cytotoxic protease and a protective immunogen from a pathogenic Vibrio harveyi strain. Vaccine 28:1041-1047

Chin YK, Al-saari N, Zulperi Z, Mohd-Aris A, Salleh A, Silvaraj S, MohamA LJY, Zamri-Saad M, Ina-Salwany MY (2020) Efficacy of bath vaccination with a live attenuated Vibrio harveyi against vibriosis in Asian seabass fingerling, Lates calcarifer. Aquac Res 51:389-399

Choudhury TG, Maiti B, Venugopal MN, Karunasagar I (2019) Influence of some environmental variables and addition of r-lysozyme on efficacy of Vibrio harveyi phage for therapy. J Biosci 44:8

Colwell RR, Grimes DJ (1984) Vibrio diseases of marine fish populations. Helgolander Meeresuntersuchungen 37:265-287

Company R, Sitja-Bobadilla A, Pujalte MJ, Garay E, Alvarez-Pellitero P, Perez-Sanchez J (1999) Bacterial and parasitic pathogens in cultured common dentex, Dentex dentex L. J Fish Dis 22:299-309

Crosbie PBB, Nowak BF (2004) Immune responses of barramundi, Lates calcarifer (Bloch), after administration of an experimental Vibrio harveyi bacterin by intraperitoneal injection, anal intubation and immersion. J Fish Dis 27:623-632

Deane EE, Jia A, Qu Z, Chen J-X, Zhang X-H, Woo NYS (2012) Induction of apoptosis in sea bream fibroblasts by Vibrio harveyi haemolysin and evidence for an anti-apoptotic role of heat shock protein 70. J Fish Dis 35:287-302

Diggles BK, Moss GA, Carson J, Anderson CD (2000) Luminous vibriosis in rock lobster Jasus verreauxi (Decapoda: Palinuridae) phyllosoma larvae associated with infection by Vibrio harveyi. Dis Aquat Organ 43:127-137

Dong HT, Taengphu S, Sangsuriya P, Charoensapsri W, Phiwsaiya K, Sornwatana T, Khunrae P, Rattanarojpon T, Senapin S (2017a) Recovery of Vibrio harveyi from scale drop and muscle necrosis disease in farmed barramundi, Lates calcarifer in Vietnam. Aquaculture 473:89-96

Dong X, Wang H, Zou P, Chen J, Liu Z, Wang X, Huang J (2017b) Complete genome sequence of Vibrio campbellii strain 20130629003S01 isolated from shrimp with acute hepatopancreatic necrosis disease. Gut Pathog 9:31

Dorsch M, Lane D, Stackebrandt E (1992) Towards a phylogeny of the genus Vibrio based on 16S ribosomal RNA sequences. Int J Syst Bacteriol 42:58-63
Esmaeili A, Sotoudeh E, Morshedi V, Bagher D, Dorafshan S (2019) Effects of dietary supplementation of bovine lactoferrin on antioxidant status, immune response and disease resistance of yellowfin sea bream (Acanthopagrus latus) against Vibrio harveyi. Fish Shellfish Immunol 93:917-923

Fabbro C, Celussi M, Russell H, Del Negro P (2011) Phenotypic and genetic diversity of coexisting Listonella anguillarum, Vibrio harveyi and Vibrio chagassi recovered from skin haemorrhages of diseased sand smelt, Atherina boyeri, in the Gulf of Trieste (NE Adriatic Sea). Lett Appl Microbiol 54:153-159

Farmer JJ III. Hickman-Brenner FW (1992) The genera Vibrio and Photobacterium. In: Balows A, Trüper HG, Dworkin M, Harder W, Schleifer KH (eds) The prokaryotes. A handbook on the biology of bacteria: ecophysiology, isolation, identification, applications, 2nd edn. Springer, New York, pp 2952-3011

Farmer JJ III, Janda JM, Brenner FW, Cameron DN, Birkhead KM (2005) Genus 1. Vibrio Pacini 1854, 411AL. In: Brenner DJ, Krieg NR, Staley JT (eds) Bergey's manual of systematic bacteriology, 2nd edn. The Proteobacteria part B. The Gammaproteobacteria. Springer, New York, pp 494-546

Firmino J, Furones MD, Andree KB, Sarasquete C, Ortiz-Delgado JB, Asencio-Alcudia G, Gisbert E (2019) Contrasting outcomes of Vibrio harveyi pathogenicity in gilthead seabream, Sparus aurata and European seabass Dicentrarchus labrax. Aquaculture 511:734210

Fukasawa S, Nakamura K, Kamii A, Ohyama Y, Osumi M (1988a) Purification and properties of a proteinase from a marine luminous bacterium, Vibrio harveyi strain FLA-11. Agric Biol Chem 52:435-441

Fukasawa S, Nakamura K, Miyahira M, Kurata M (1988b) Some properties of two proteinases from a luminous bacterium, Vibrio harveyi strain FLN-108. Agric Biol Chem 52:3009-3014

Gauger EJ, Gomez-Chiarri M (2002) 16S ribosomal DNA sequencing confirms the synonymy of Vibrio harveyi and V. carchariae. Dis Aquat Org 52:39-46

Gauger E, Smolowitz R, Uhlinger K, Casey J, Gómez-Chiarri M (2006) Vibrio harveyi and other bacterial pathogens in cultured summer flounder, Paralichthys dentatus. Aquaculture 260:10-20

Geng X, Dong X-H, Tan B-P, Yang Q-H, Chi S-Y, Liu H-Y, Liu X-Q (2012) Effects of dietary probiotic on the growth performance, non-specific immunity and disease resistance of cobia, Rachycentron canadum. Aquac Nutr 18:46-55

Gomez-Gil B, Soto-Rodriquez S, Garcia-Gasca A, Roque A, VazquezJuarez R, Thompson FL, Swings J (2004) Molecular identification of Vibrio harveyi-related isolates associated with diseased aquatic organisms. Microbiology 150:1769-1777

Grimes DJ, Stemmler J, Hada H, May EB, Maneval D, Hetrick FM, Jones RT, Stoskopf M, Colwell RR (1984) Vibrio species associated with mortality of sharks held in captivity. Microb Ecol 10:271-282

Grimes DJ, Gruber SH, May EB (1985) Experimental infection of lemon sharks, Negaprion brevirostris (Poey), with Vibrio species. J Fish Dis 8:173-180

Gupta A, Verma G, Gupta P (2016) Growth performance, feed utilization, digestive enzyme activity, innate immunity and protection against Vibrio harveyi of freshwater prawn, Macrobrachium rosenbergii fed diets supplemented with Bacillus coagulans. Aquac Int 24:1379-1392

Haldar S, Maharajan A, Chatterjee S, Hunter SA, Chowdhury N, Hinenoya A, Asakura M, Yamasaki S (2010) Identification of Vibrio harveyi as a causative bacterium for a tail rot disease of sea bream Sparus aurata from research hatchery in Malta. Microbiol Res 165:639-648

Han JE, Tang KFJ, Aranguren LF, Piamsomboon P (2017) Characterization and pathogenicity of acute hepatopancreatic necrosis 
disease natural mutants, pirAB(vp) (-) V. parahaemolyticus, and $\operatorname{pirAB}(v p)(+) V$. campbellii strains. Aquaculture 470:84-90

Harikrishnan R, Balasundaram C, Jawahar S, Heo M-S (2011a) Solanum nigrum enhancement of the immune response and disease resistance of tiger shrimp, Penaeus monodon against Vibrio harveyi. Aquaculture 318:67-73

Harikrishnan R, Balasundaram C, Heo M-S (2011b) Influence of diet enriched with green tea on innate humoral and cellular immune response of kelp grouper (Epinephelus bruneus) to Vibrio carchariae infection. Fish Shellfish Immunol 30:972-979

Harikrishnan R, Balasundaram C, Heo M-S (2012a) Effect of Inonotus obliquus enriched diet on hematology, immune response, and disease protection in kelp grouper, Epinephelus bruneus against Vibrio harveyi. Aquaculture 344-349:48-53

Harikrishnan R, Kim JS, Balasundaram C, Heo M-S (2012b) Protection of Vibrio harveyi infection through dietary administration of Pueraria thunbergiana in kelp grouper, Epinephelus bruneus. Aquaculture 324:27-32

Harikrishnan R, Kim J-S, Balasundaram C, Heo M-S (2012c) Vaccination effect of liposomes entrapped whole cell bacterial vaccine on immune response and disease protection in Epinephelus bruneus against Vibrio harveyi. Aquaculture 342:69-74

Harikrishnan R, Kim J-S, Kim M-C, Balasundaram C, Heo M-S (2012d) Zanthoxylum piperitum supplemented diet enhances disease resistance in Epinephelus bruneus against Vibrio carchariae. Fish Pathol 47:27-29

Harries LJ, Owens L (1999) Production of exotoxins by two luminous Vibrio harveyi strains known to be primary pathogens of Penaeus monodon larvae. Dis Aquat Org 38:11-22

Henke JM, Bassler BL (2004) Quorum sensing regulates type III secretion in Vibrio harveyi and Vibrio parahaemolyticus. J Bacteriol 186:3794-3805

Hispano C, Nebra Y, Blanch AR (1997) Isolation of Vibrio harveyi from an ocular lesion in the short sunfish (Mola mola). Bull Eur Assoc Fish Pathol 17:104-107

Hoffmann M, Monday SR, Fischer M, Brown EW (2012) Genetic and phylogenetic evidence for misidentification of Vibrio species within the Harveyi clade. Lett Appl Microbiol 54:160-165

Hu Y-H, Sun L (2011) A bivalent Vibrio harveyi DNA vaccine induces strong protection in Japanese flounder (Paralichthys olivaceus). Vaccine 29:4328-4333

Hu Y-H, Cheng S, Zhang M, Sun L (2011) Construction and evaluation of a live vaccine against Edwardsiella tarda and Vibrio harveyi: laboratory vs. mock field trial. Vaccine 29:4081-4085

Huang ZJ, Tang JJ, Li M, Fu YC, Dong CF, Zhong JF, He JG (2012) Immunological evaluation of Vibrio alginolyticus, Vibrio harveyi, Vibrio vulnificus and infectious spleen and kidney necrosis virus (ISKNV) combined-vaccine efficacy in Epinephelus coioides. Vet Immunol Immunopathol 150:61-68

Ishimaru K, Muroga K (1997) Taxonomical re-evaluation of two pathogenic Vibrio species isolated from milkfish and swimming crab. Fish Pathol 32:59-64

Iwamoto Y, Suzuki Y, Kurita A, Watanabe Y, Shimizu T, Ohgami H, Yanagihara Y (1995) Vibrio trachuri sp. nov., a new species isolated from diseased Japanese horse mackerel. Microbiol Immunol 39:831-837

Jin G, Wang S, Yu M, Yan S, Zhang X-H (2010) Identification of a marine antagonistic strain JG1 and establishment of a polymerase chain reaction detection technique based on the $\operatorname{gyr} B$ gene. Aquac Res 41:1867-1874

Johnson FH, Shunk IV (1936) An interesting new species of luminous bacteria. J Bacteriol 31:585-592

Kannappan S, Sivakumar K, Sethi S (2018) Protective effect of mangrove (Rhizophora apiculata) leaves extract in shrimp (Penaeus monodon) larvae against bio-luminescent diseasecausing Vibrio harveyi bacteria. Span J Agric Res 16:e501
Karunasagar I, Pai R, Malathi GR, Karunasagar I (1994) Mass mortality of Penaeus monodon larvae due to antibiotic-resistant Vibrio harveyi infection. Aquaculture 128:203-209

Ke H-M, Prachumwat A, Yu C-P, Yang Y-T, Promsri S, Liu K-F, Lo C-F, Lu M-YJ, Lai M-C, Tsai IJ, Li W-H (2017) Comparative genomics of Vibrio campbellii strains and core species of the Vibrio harveyi clade. Sci Rep 7:41394

Khemayan K, Pasharawipas T, Puiprom O, Sriurairatana S, Suthienkul O, Flegel TW (2006) Unstable lysogeny and pseudolysogeny in Vibrio harveyi siphovirus-like phage 1. Appl Environ Microbiol 72:1355-1363

Kim J-S, Harikrishnan R, Kim M-C, Jang I-S, Kim D-H, Hong S-H, Balasundaram C, Heo M-S (2011) Enhancement of Eriobotrya japonica extracts on non-specific immune response and disease resistance in kelp grouper Epinephelus bruneus against Vibrio carchariae. Fish Shellfish Immunol 31:1193-1200

Kraxberger-Beatty T, McGarey DJ, Grier HJ, Lim DV (1990) Vibrio harveyi, an opportunistic pathogen of common snook, Centropomus undecimalis (Block), held in captivity. J Fish Dis 13:557-560

Lal TM, Sano M, Ransangan J (2017) Isolation and characterization of large marine bacteriophage (Myoviridae), VhKM4 infecting Vibrio harveyi. J Aquat Anim Health 29:26-30

Lee CA (1996) Pathogenicity islands and the evolution of bacterial pathogens. Infect Agents Dis 5:1-7

Lee J-H, Kim J-W, Kang W-J, Ko D-W, Kim J-M, Choi S-H, Park K-H (2018) Effects of beta-1,3-glucan on innate immunity responses and mortality induced by Vibrio harveyi, hemorrhagic septicemia virus, or Miamiensis avidus in the olive flounder Paralichthys olivaceus. Aquac Int 26:743-756

Lee KK, Liu PC, Kou GH, Chen SN (1997) Investigation on the major exotoxin of Vibrio harveyi 770527 isolated from diseased Penaeus monodon. Rep Fish Dis Res 18:33-42

Lee KK, Liu PC, Chuang WH (2002) Pathogenesis of gastroenteritis caused by Vibrio carchariae in cultured marine fish. Mar Biotechnol 4:267-277

Li H, Xiao J, Zhou Y, Wang Q, Zhang Y (2017) Sensitivity improvement of rapid Vibrio harveyi detection with an enhanced chemiluminescent-based dot blot. Lett Appl Microbiol 65:206-212

Li M-F, Wang C-L, Sun L (2011) A pathogenic Vibrio harveyi lineage causes recurrent disease outbreaks in cultured Japanese flounder (Paralichthys olivaceus) and induces apoptosis in host cells. Aquaculture 319:30-36

Lin H, Yu M, Wang X, Zhang X-H (2018) Comparative genomic analysis reveals the evolution and environmental adaptation strategies of vibrios. BMC Genomics 19:135

Liu L, Ge M, Zheng X, Tao Z, Zhou S, Wang G (2016) Investigation of Vibrio alginolyticus, $V$. harveyi and $V$. parahaemolyticus in large yellow croaker, Pseudosciaena crocea (Richardson) reared in Xiangshan Bay. China Aquac Rep 3:220-224

Liu PC, Lee KK, Chen SN (1996) Pathogenicity of different isolates of Vibrio harveyi in tiger prawn, Penaeus monodon. Lett Appl Microbiol 22:413-416

Liu PC, Lee KK, Tu CC, Chen SN (1997) Purification and characterization of a cysteine protease produced by pathogenic luminous Vibrio harveyi. Curr Microbiol 35:32-39

Liu P-C, Chuang W-H, Lee K-K (2003) Infectious gastroenteritis caused by Vibrio harveyi (V. carchariae) in cultured red drum (Sciaenops ocellatus). J Appl Ichthyol 19:59-61

Mao Z, He C, Qiu Y, Chen J (2011) Expression of Vibrio harveyi ompK in the yeast Pichia pastoris: the first step in developing an oral vaccine against vibriosis? Aquaculture 318:268-272

Mohamad N, Roseli FAM, Azmai MNA, Saad MZ, Yasin ISM, Zulkiply NA, Nasruddin NS (2019) Natural concurrent 
infection of Vibrio harveyi and V. alginolyticus in cultured hybrid groupers in Malaysia. J Aquat Anim Health 31:88-96

Mohd-Aris A, Saad MZ, Daud HM, Yusof MT, Ina-Salwany MY (2019) Vibrio harveyi protease deletion mutant as a live attenuated vaccine candidate against vibriosis and transcriptome profiling following vaccination for Epinephelus fuscoguttatus. Aquac Int 27:125-140

Mohi MM, Kuratani M, Miyazaki T, Yoshida T (2010) Histopathological studies of Vibrio harveyi-sinfected tiger puffer, Takifugu rubripes (Temminck et Schlegel), cultured in Japan. J Fish Dis 33:833-840

Montero AB, Austin B (1999) Characterization of extracellular products from an isolate of Vibrio harveyi recovered from diseased post-larval Penaeus vannamei (Bonne). J Fish Dis 22:377-386

Montgomery MT, Kirchman DL (1993) Role of chitin binding proteins in the specific attachment of the marine bacterium Vibrio harveyi to chitin. Appl Environ Microbiol 59:373-379

Montgomery MT, Kirchman DL (1994) Induction of chitin-binding proteins during the specific attachment of the marine bacterium Vibrio harveyi to chitin. Appl Environ Microbiol 60:4284-4288

Munro J, Oakey J, Bromage E, Owens L (2003) Experimental bacteriophage-mediated virulence in strains of Vibrio harveyi. Dis Aquat Organ 54:187-194

Muthukrishnan S, Defoirdt T, Ina-Salwany MY, Yusoff FM, Shariff M, Ismail SI, Natrah I (2019) Vibrio parahaemolyticus and Vibrio harveyi causing Acute Hepatopancreatic Necrosis Disease (AHPND) in Penaeus vannamei (Boone, 1931) isolated from Malaysian shrimp ponds. Aquaculture 511:734227

Nakayama T, Nomura N, Matsumura M (2005) Analysis of the relationship between luminescence and toxicity of Vibrio carchariae pathogenic to shrimp. Fish Sci 71:1236-1242

Nguyen HT, Nguyen TTT, Wang T, Wang C, Chen C (2017) Effectiveness of formalin-killed vaccines containing CpG oligodeoxynucleotide 1668 adjuvants against Vibrio harveyi in orange-spotted grouper. Fish Shellfish Immunol 68:124-131

Nguyen HT, Nguyen TTT, Chen Y-C, Vu-Khac H, Wang P-C, Chen S-C (2018) Enhanced immune responses and effectiveness of refined outer membrane protein vaccines against Vibrio harveyi in orange-spotted grouper (Epinephelus coioides). J Fish Dis 41:1349-1358

Nishibuchi M, Kaper JB (1985) Nucleotide sequence of the thermostable direct hemolysin gene of Vibrio parahaemolyticus. J Bacteriol 162:558-564

Nishimori E, Hasegawa O, Numata T, Wakabayashi H (1998) Vibrio carchariae causes mass mortalities in Japanese abalone, Sulculus diversicolor supratexta. Fish Pathol 33:495-502

Oakey HJ, Owens L (2000) A new bacteriophage, VHML, isolated from a toxin-producing strain of Vibrio harveyi in tropical Australia. J Appl Microbiol 89:702-709

Oakey HJ, Cullen BR, Owens L (2002) The complete nucleotide sequence of the Vibrio harveyi bacteriophage VHML. J Appl Microbiol 93:1089-1098

Oliver JD (2010) Recent findings on the viable but nonculturable state in pathogenic bacteria. FEMS Microbiol Rev 34:415-425

Owens L, Austin DA, Austin B (1996) Effect of siderophore production in Vibrio harveyi isolates. Dis Aquat Organ 27:157-160

Pang H-Y, Li Y, Wu Z-H, Jian J-C, Lu Y-S, Cai S-H (2010) Immunoproteomic analysis and identification of novel immunogenic proteins from Vibrio harveyi. J Appl Microbiol 109:1800-1809

Pang JH, Wang Q, Fei YJ, Zhua P, Qiao LL, Huang HL, Dang CY, Gao WF (2019) A real-time recombinase polymerase amplification assay for the rapid detection of Vibrio harveyi. Mol Cell Probes 44:8-13

Pang L, Zhang X-H, Zhong Y, Chen J, Li Y, Austin B (2006) Identification of Vibrio harveyi using PCR amplification of the toxR gene. Lett Appl Microbiol 43:249-255
Pasharawipas T, Thaikua S, Sriurairatana S, Ruangpan L, Direkbusarakum S, Manopvisetcharean J, Flegel TW (2005) Partial characterization of a novel bacteriophage of Vibrio harveyi isolated from shrimp culture ponds in Thailand. Virus Res 114:63-69

Pavia AT, Bryan JA, Maher KL, Hester TR, Farmer JJ (1989) Vibrio carchariae infection after a shark bite. Ann Intern Med 111:85-86

Pedersen K, Verdonck L, Austin B, Austin DA, Blanch AR, Grimont PAD, Jofre J, Koblavi S, Larsen JL, Tiainen T, Vigneulle M, Swings J (1998) Taxonomic evidence that Vibrio carchariae Grimes et al 1985 is a junior synonym of Vibrio harveyi (Johnson and Shunk 1936) Baumann et al. 1981. Int J Syst Bacteriol 48:749-758

Pinto MF, Baptista T, Afonso TTN (2017) Development of a new multiplex-PCR tool for the simultaneous detection of the fish pathogens Vibrio alginolyticus, Vibrio anguillarum, Vibrio harveyi and Edwardsiella tarda. Aquat Living Res 30:4

Prasad S, Morris PC, Hansen R, Meaden PG, Austin B (2005) A novel bacteriocin-like substance (BLIS) from a pathogenic strain of Vibrio harveyi. Microbiology 151:3051-3058

Prayitno SB, Latchford JW (1995) Experimental infections of crustaceans with luminous bacteria related to Photobacterium and Vibrio-effect of salinity and $\mathrm{pH}$ on infectiosity. Aquaculture 132:105-112

Pujalte MJ, Sitjá-Bobadilla A, Macián MC, Belloch C, Álvarez-Pellitero P, Pérez-Sánchez J, Uruburu F, Garay E (2003) Virulence and molecular typing of Vibrio harveyi strains isolated from cultured dentex, gilthead sea bream and European sea bass. Syst Appl Microbiol 26:284-292

Qin G, Wang X, Tan S, Lin Q (2017) A bacterial infection by Vibrio harveyi causing heavy reduction of cultured lined seahorse Hippocampus erectus. J Fish Dis 40:601-605

Qin YX, Wang J, Su YQ, Wang DX, Chen XZ (2006) Studies on the pathogenic bacterium of ulcer disease in Epinephelus awoara. Acta Oceanol Sin 25:154-159

Raj ST, Lipton AP, Chauhan GS (2010) Characterization and infectivity evaluation of Vibrio harveyi causing white patch disease among captive reared seahorses, Hippocampus kuda. Indian J Mar Sci 39:151-156

Ransangan J, Mustafa S (2009) Identification of Vibrio harveyi isolated from diseased Asian sea bass Lates calcarifer by use of $16 \mathrm{~S}$ ribosomal DNA sequencing. J Aquat Anim Health 21:150-155

Restrepo L, Bayot B, Arciniegas S, Bajana L, Betancourt I, Panchana F, Munoz AR (2018) PirVP genes causing AHPND identified in a new Vibrio species (Vibrio punensis) within the commensal Orientalis clade. Sci Rep 8:13080

Robertson PAW, Caldero J, Carrera L, Stark JR, Zherdmant M, Austin B (1998) Experimental Vibrio harveyi infections in Penaeus vannamei larvae. Dis Aquat Organ 32:151-155

Ruangpan L, Danayadol Y, Direkbusarakom S, Siurairatana S, Flegel TW (1999) Lethal toxicity of Vibrio harveyi to cultivated Penaeus monodon induced by a bacteriophage. Dis Aquat Organ 35:195-201

Saeed MO (1995) Association of Vibrio harveyi with mortalities in cultured marine fish in Kuwait. Aquaculture 136:21-29

Schaeck M, Duchateau L, Van den Broeck W, Van Trappen S, De Vos P, Coulombet C, Boon N, Haesebrouck F, Decostere A (2016) Vibrio lentus protects gnotobiotic sea bass (Dicentrarchus labrax L.) larvae against challenge with Vibrio harveyi. Vet Microbiol 185:41-48

Selvin J, Huxley AJ, Lipton AP (2005) Pathogenicity, antibiogram and biochemical characteristics of luminescent Vibrio harveyi associated with 'Black Shell Disease' of Penaeus monodon. Fish Technol 42:191-196 
Shen GM, Shi CY, Fan C, Jia D, Wang SQ, Xie GS, Li GY, Mo ZL, Huang J (2017) Isolation, identification and pathogenicity of Vibrio harveyi, the causal agent of skin ulcer disease in juvenile hybrid groupers Epinephelus fuscoguttatus x Epinephelus lanceolatus. J Fish Dis 40:1351-1362

Soffientino B, Gwaltney T, Nelson DR, Specker JL, Mauel M, GomezChiarri M (1999) Infectious necrotizing enteritis and mortality caused by Vibrio carchariae in summer flounder Paralichthys dentatus during intensive culture. Dis Aquat Org 38:201-210

Soto-Rodriguez SA, Roque A, Lizarraga-Partida ML, Guerra-Flores AL, Gomez-Gil B (2003) Virulence of luminous vibrios to Artemia franciscana nauplii. Dis Aquat Organ 53:231-240

Stalin N, Srinivasan P (2017) Efficacy of potential phage cocktails against Vibrio harveyi and closely related Vibrio species isolated from shrimp aquaculture environment in the south east coast of India. Vet Microbiol 207:83-96

Sun BG, Zhang X-H, Tang XX, Wang SS, Zhong YB, Chen JX, Austin B (2007) A single residue change in Vibrio harvei hemolysin results in the loss of phospholipase and haemolytic activities and pathogenicity for turbot (Scophthalmus maximus). $\mathrm{J}$ Bacteriol 189:2575-2579

Sun F, Chen J, Zhong L, Zhang X-H, Wang R, Guo Q, Dong Y (2008) Characterization and virulence retention of viable but nonculturable cells. FEMS Microbiol Ecol 64:37-44

Sun K, Hu Y-H, Zhang X-H, Bai F-F, Sun L (2009) Identification of vhhP2, a novel genetic marker of Vibrio harveyi, and its application in the quick detection of $V$. harveyi from animal specimens and environmental samples. J Appl Microbiol 107:1251-1257

Talpur AD, Ikhwanuddin M (2012) Dietary effects of garlic (Allium sativum) on haemato-immunological parameters, survival, growth, and disease resistance against Vibrio harveyi infection in Asian sea bass, Lates calcarifer (Bloch). Aquaculture 364:6-12

Tan XH, Sun ZZ, Huang Z, Zhou CP, Lin HZ, Tan LJ, Xun PW, Huang Q (2017) Effects of dietary hawthorn extract on growth performance, immune responses, growt- and immune-related genes expression of juvenile golden pompano (Trachinotus ovatus) and its susceptibility to Vibrio harveyi infection. Fish Shellfish Immunol 70:656-664

Thompson FL, Hoste B, Vandemeulebroecke K, Engelbeen K, Denys R, Swings J (2002) Vibrio trachuri Iwamoto et al. 1995 is a junior synonym of Vibrio harveyi (Johnson and Shunk 1936) Baumann et al. 1981. Int J Syst Evol Microbiol 52: 973-976

Thompson FL, Gomez-Gil B, Vasconcelos ATR, Sawabe T (2007) Multilocus sequence analysis reveals that Vibrio harveyi and V. campbellii are distinct species. Appl Environ Microbiol 73:4279-4285

Urbanczyk H, Ogura Y, Hayashi T (2013) Taxonomic revision of Harveyi clade bacteria (family Vibrionaceae) based on analysis of whole genome sequences. Int J Syst Evol Microbiol 63:2742-2751

Verma VK, Rani KV, Kumar SR, Prakash O (2018) Leucaena leucocephala pod seed protein as an alternative to animal protein in fish feed and evaluation of its role to fight against infection caused by Vibrio harveyi and Pseudomonas aeruginosa. Fish Shellfish Immunol 76:324-332

Vidgen M, Carson J, Higgins M, Owens L (2006) Changes to the phenotypic profile of Vibrio harveyi myovirus-like (VHML) bacteriophage. J Appl Microbiol 100:481-487

Wang B-K, Yu J-H, Li Y, Ji W-S, Xu H-S (2002) Isolation and identification of pathogen (Vibrio harveyi) from sea pearch, Lateolabrax japonicus. J Fishery Sci 9:52-55 (in Chinese, abstract in English)

Wang C, Zhang X-H, Jia A, Chen J, Austin B (2008) Identification of immune-related genes from kidney and spleen of turbot, Psetta maxima (L.), by suppression subtractive hybridization following challenge with Vibrio harveyi. J Fish Dis 31:505-514

Wang HY, Zhu F, Huang YC, Ding Y, Jian JC, Wu ZH (2017) Construction of glutathione peroxidase (GPx) DNA vaccine and its protective efficiency on the orange-spotted grouper (Epinephelus coioides) challenged with Vibrio harveyi. Fish Shellfish Immunol 60:529-536

Wang Q, Chen J, Liu R, Jia J (2011) Identification and evaluation of an outer membrane protein OmpU from a pathogenic Vibrio harveyi isolate as vaccine candidate in turbot (Scophthalmus maximus). Lett Appl Microbiol 53:22-29

Wang RX, Yao T, Liu XJ, Wang JY (2018) Isolation and characterisation of Vibrio harveyi as etiological agent of foot pustule disease in the abalone Haliotis discus hannai Ino 1953. Indian J Fish 65:79-85

Won KM, Park S (2008) Pathogenicity of Vibrio harveyi to cultured marine fishes in Korea. Aquaculture 285:8-13

Xiao J, Liu L, Ke Y, Li X, Liu Y, Pan Y, Yan S, Wang Y (2017) Shrimp AHPND-causing plasmids encoding the PirAB toxins as mediated by pirAB-Tn903 are prevalent in various Vibrio species. Sci Rep 7:42177

Xu H-S, Roberts N, Singleton FL, Attwell RW, Grimes DJ, Colwell R (1982) Survival and viability of nonculturable Escherichia coli and Vibrio cholerae in the estuarine and marine environment. Microb Ecol 8:313-323

Xu XD, Lui KF, Wang SF, Guo WL, Xie ZY, Zhou YC (2017) Identification of pathogenicity, investigation of virulent gene distribution and development of a virulent strain-specific detection PCR method for Vibrio harveyi isolated from Hainan province and Guangdong province, China. Aquaculture 468:226-234

Xu WT, Jiao CL, Bao PC, Liu Q, Wang PB, Zhang RL, Liu XH, Zhang YX (2019) Efficacy of Montanide (TM) ISA 763 A VG as aquatic adjuvant administrated with an inactivated Vibrio harveyi vaccine in turbot (Scophthalmus maximus L.). Fish Shellfish Immunol 84:56-61

Yang Q, Han Y, Zhang X-H (2011) Detection of quorum-sensing signal molecules in the family Vibrionaceae. J Appl Microbiol 110:1438-1448

Yii K-C, Yang TI, Lee K-K (1997) Isolation and characterization of Vibrio carchariae, a causative agent of gastroenteritis in the groupers, Epinephelus coioides. Curr Microbiol 35:109-115

Yu M, Wang J, Tang K, Shi X, Wang S, Zhu W-M, Zhang X-H (2012) Purification and characterization of antibacterial compounds of Pseudoalteromonas flavipulchra JG1. Microbiology-SGM 158:835-842

Zhang C, Yu L, Qian R (2008) Cloning and expression of Vibrio harveyi $\mathrm{OmpK}^{*}$ and $\mathrm{GAPDH}^{*}$ genes and their potential application as vaccines in large yellow croakers Pseudosciaena crocea. J Aquat Anim Health 20:1-11

Zhang X-H (2001) Studies on the pathogenicity mechanisms of the fish pathogen Vibrio harveyi. $\mathrm{PhD}$ thesis, Heriot-Watt University, UK.

Zhang X-H, Austin B (2000) Pathogenicity of Vibrio harveyi to salmonids. J Fish Dis 23:93-102

Zhang X-H, Lin H, Wang X, Austin B (2018) Significance of Vibrio species in the marine organic carbon cycle-a review. Sci China Earth Sci 61:1357-1368

Zhang X-H, Meaden PG, Austin B (2001) Duplication of hemolysin genes in a virulent isolate of Vibrio harveyi. Appl Environ Microbiol 67:3161-3167

Zhong Y, Zhang X-H, Chen J, Chi Z, Sun B, Li Y, Austin B (2006) Overexpression, characterization, and pathogenicity of Vibrio harveyi hemolysin VHH. Infect Immun 74:6001-6005

Zhou CP, Lin HZ, Xia DM, Yang K, Yang YY, Huang Z, Wei Y (2016) Effect of dietary marine red yeast Rhodotorula mucilaginosa on the growth performance, and also non-specific immune responses 
of juvenile golden pompano Trachinotus ovatus when challenged with Vibrio harveyi. Israeli J Aquacult-BAMIDGEH 68: 1262

Zhou J, Fang W, Yang X, Zhou S, Hu L, Li X, Qi X, Su H, Xie L (2012) A nonluminescent and highly virulent Vibrio harveyi strain is associated with "Bacterial White Tail Disease" of Litopenaeus vannamei shrimp. PLoS ONE 7:e29961

Zhu K, Chi Z, Li J, Zhang F, Li M, Yasoda HN, Wu L (2006) The surface display of haemolysin from Vibrio harveyi on yeast cells and their potential applications as live vaccines in marine fish. Vaccine 24:6046-6052

Zhu ZM, Dong CF, Weng SP, He JG (2018) The high prevalence of pathogenic Vibrio harveyi with multiple antibiotic resistance in scale drop and muscle necrosis disease of the hybrid grouper,
Epinephelus fuscoguttatus (ㅇ) x E. lanceolatus (ð), in China. $\mathrm{J}$ Fish Dis 41:589-601

Zhu ZM, Dong CF, Weng SP, He JG (2019) Identification of outer membrane protein To1C as the major adhesin and potential vaccine candidate for Vibrio harveyi in hybrid grouper, Epinephelus fuscoguttatus (female) x E-lanceolatus (male). Fish Shellfish Immunol 86:143-151

Zorrilla I, Arijo S, Chabrillon M, Diaz P, Martinez-Manzanares E, Balebona MC, Morinigo MA (2003) Vibrio species isolated from diseased farmed sole, Solea senegalensis (Kaup), and evaluation of the potential virulence role of their extracellular products. J Fish Dis 26:103-108 